\title{
Transition and Alkali Metal Complex Ternary Amides for Ammonia Synthesis and Decomposition
}

\author{
Hujun Cao, ${ }^{[a]} \ddagger$ Jianping Guo, ${ }^{[b] \ddagger}$ Fei Chang, ${ }^{[b]}$ Claudio Pistidda, ${ }^{[a]}$ Wei Zhou, ${ }^{[c]}$ Xilun Zhang, ${ }^{[b]}$ Antonio \\ Santoru, ${ }^{[a]}$ Hui Wu, ${ }^{[c]}$ Norbert Schell, ${ }^{[d]}$ Rainer Niewa, ${ }^{[e]}$ Ping Chen, ${ }^{[b]}$ Thomas Klassen, ${ }^{[a]}$ and Martin \\ Dornheim $^{[a]}$
}

\begin{abstract}
A new complex ternary amide $R b_{2}\left[\mathrm{Mn}\left(\mathrm{NH}_{2}\right)_{4}\right]$, which simultaneously contains both transition and alkali metal catalytic sites, is developed. This is in line with the recently reported TM$\mathrm{LiH}$ composite catalysts, which have been shown to effectively break the scaling relations and achieve ammonia synthesis under mild conditions. $R b_{2}\left[\mathrm{Mn}\left(\mathrm{NH}_{2}\right)_{4}\right]$ can be facilely synthesized by mechanochemical reaction at room temperature. It exhibits two temperature-dependent polymorphs i.e. low-temperature orthorhombic and high-temperature monoclinic structures. $R b_{2}\left[\mathrm{Mn}\left(\mathrm{NH}_{2}\right)_{4}\right]$ decomposes to $\mathrm{N}_{2}, \mathrm{H}_{2}, \mathrm{NH}_{3}, \mathrm{Mn}_{3} \mathrm{~N}_{2}$, and $\mathrm{RbNH}$ under inert atmosphere; whereas releases $\mathrm{NH}_{3}$ at a temperature as low as $80{ }^{\circ} \mathrm{C}$ under $\mathrm{H}_{2}$ atmosphere. Those unique behaviors enable $\mathrm{Rb} b_{2}\left[\mathrm{Mn}\left(\mathrm{NH}_{2}\right)_{4}\right]$ and its analogue $\mathrm{K}_{2}\left[\mathrm{Mn}\left(\mathrm{NH}_{2}\right)_{4}\right]$ as excellent catalytic materials for ammonia decomposition and synthesis. Our experimental results show both ammonia decomposition onset temperatures and conversion rates over $R b_{2}\left[\mathrm{Mn}\left(\mathrm{NH}_{2}\right)_{4}\right]$ and $\mathrm{K}_{2}\left[\mathrm{Mn}\left(\mathrm{NH}_{2}\right)_{4}\right]$ are similar to those of noble metal Ru-based catalysts. More importantly, these ternary amides exhibit superior capabilities in catalyzing $\mathrm{NH}_{3}$ synthesis, which are more than 3 orders of magnitude higher than that of Mn nitride and twice of that of Ru/MgO. The in-situ SR-PXD measurement discloses that manganese nitride synergistic with $\mathrm{Rb} / \mathrm{KH}$ or $\mathrm{Rb} / \mathrm{K}\left(\mathrm{NH}_{2}\right)_{\mathrm{x}} \mathrm{H}_{1-\mathrm{x}}$ are likely the active sites. The chemistry of $R b_{2} / K_{2}\left[M n\left(N_{2}\right)_{x}\right]$ and $\mathrm{Rb} / \mathrm{K}_{(}\left(\mathrm{NH}_{2}\right)_{x} \mathrm{H}_{1-x}$ with $\mathrm{H}_{2} / \mathrm{N}_{2}$ and $\mathrm{NH}_{3}$ correlates closely with the catalytic performance.
\end{abstract}

Inorganic metal amides have attracted increasing attention as potential hydrogen storage materials ${ }^{[1]}$ and ammonia decomposition catalyst precursors. ${ }^{[2]}$ Among them, ternary alkali metal transition metal amides $\left(\mathrm{A}\left[\mathrm{M}\left(\mathrm{NH}_{2}\right)_{\mathrm{x}}\right], \mathrm{A}=\right.$ alkalis, $\mathrm{M}=$ transition metals ) such as $\mathrm{A}_{2}\left[\mathrm{Mn}\left(\mathrm{NH}_{2}\right)_{4}\right]^{[3]}(\mathrm{A}=\mathrm{Na}, \mathrm{K})$,

[a] Dr. H. Cao, Dr. C. Pistidda, Mr. A. Santoru, Prof. T. Klassen, Dr. M. Dornheim

Institute of Materials Research, Materials Technology, HelmholtzZentrum Geesthacht GmbH, Max-Planck-Straße 1, D-21502

Geesthacht, Germany.

E-mail: hujun.cao@hzg.de

[b] Prof. H. Wu, Prof. W. Zhou

NIST Center for Neutron Research, National Institute of Standards and Technology, Gaithersburg, Maryland 20899-6102, USA

E-mail: huiwu@nist.gov

[c] Mr. F. Chang, Mr. X. Zhang, Dr. J. Guo, Prof. P. Chen Dalian National Laboratory for Clean Energy Dalian Institute of Chemical Physics, Chinese Academy of Sciences, Dalian 116023, PR China

[d] Prof. N. Schell

Helmholtz-Zentrum Geesthacht, Institute of Materials Science, Notkestraße 85, 22607 Hamburg, Germany

[e] Prof. R. Niewa

Institute of Inorganic Chemistry, University Stuttgart, Pfaffenwaldring 55, Stuttgart 70569, Germany

Supporting information for this article is given via a link at the end of the document.
$\mathrm{A}_{2}\left[\mathrm{Zn}\left(\mathrm{NH}_{2}\right)_{4}\right](\mathrm{A}=\mathrm{K}, \mathrm{Rb}, \mathrm{Cs})^{[3 \mathrm{~b}, 4]}$ are important intermediates for hydrogen storage ${ }^{[5]}$ and synthesis of transition metal nitrides (TMNs) ${ }^{[6]}$ In general, transition metal amides are synthesized by ammonothermal reaction, ${ }^{[6]}$ and the formation process needs high pressures, high temperatures and long reaction times. For instance, monoclinic $\left(P 2_{1} / c\right) \mathrm{K}_{2}\left[\mathrm{Zn}\left(\mathrm{NH}_{2}\right)_{4}\right]$ was synthesized by reaction of metallic $\mathrm{Zn}$ and $\mathrm{KNH}_{2}$ at $450{ }^{\circ} \mathrm{C}$ and $249 \mathrm{MPa}$ of $\mathrm{NH}_{3}$ for more than 7 days (reaction 1). ${ }^{[7]}$

$2 \mathrm{KNH}_{2}+\mathrm{Zn}+2 \mathrm{NH}_{3} \rightarrow \mathrm{K}_{2}\left[\mathrm{Zn}\left(\mathrm{NH}_{2}\right)_{4}\right]+\mathrm{H}_{2}$

Very recently, we have produced $\mathrm{K}_{2}\left[\mathrm{Zn}\left(\mathrm{NH}_{2}\right)_{4}\right]$ and $\mathrm{K}_{2}\left[\mathrm{Mn}\left(\mathrm{NH}_{2}\right)_{4}\right]$ by one-pot mechanochemical reaction at room temperature (RT) for the first time. After mixing them with $\mathrm{LiH}$, they show excellent hydrogenation properties, e.g., both can absorb ca. 3 wt \% of $\mathrm{H}_{2}$ within 1 min under 50 bar of $\mathrm{H}_{2}$ at $230^{\circ} \mathrm{C}$. Upon heating to $500^{\circ} \mathrm{C}$ under vacuum, $\mathrm{K}_{2}\left[\mathrm{Mn}\left(\mathrm{NH}_{2}\right)_{4}\right]-8 \mathrm{LiH}$ converts to an excellent electrode material $\mathrm{Li}_{7}\left[\mathrm{MnN}_{4}\right]$ and $\mathrm{Mn}_{4} \mathrm{NN}^{\left[{ }^{[5 b]}\right]}$ This shows a new route to synthesize TMNs. And TMNs can also be prepared upon heating ternary transition amides individually, e.g. the $\mathrm{Li}_{4}\left[\mathrm{Zn}\left(\mathrm{NH}_{2}\right)_{4}\right]\left(\mathrm{NH}_{2}\right)_{2}$ turns into $\mathrm{LiNH}_{2} / \mathrm{Li}_{2} \mathrm{NH}$ and $\mathrm{LiZnN}$ upon heating. ${ }^{[8]}$

Apart from the applications in hydrogen storage and producing transition metal nitrides, ternary transition metal amides may also be used in other areas such as using for ammonia synthesis and decomposition. Having both transition metals and alkalis, the ternary amides $\left(\mathrm{A}\left[\mathrm{M}\left(\mathrm{NH}_{2}\right)_{\mathrm{x}}\right]\right)$ contain key elements of catalysts that are widely applied in catalytic ammonia synthesis and decomposition, where TM is the active metal, $A$ is the promoter. Moreover, it is well known that in both ammonia decomposition and synthesis, $\mathrm{NH}_{\mathrm{x}}(\mathrm{x}=0,1$ and 2) species are the key intermediates on the transition metal surfaces. ${ }^{\left[{ }^{[]}\right.}$And it also has been proposed that a surface metal amide or imide $\left(-\mathrm{NH}_{2}\right.$ or $-\mathrm{NH})$ may be the abundant species with the presence of alkalis. ${ }^{[10]}$ In the structure of ternary transition metal amides, e.g., $\mathrm{K}_{2}\left[\mathrm{Mn}\left(\mathrm{NH}_{2}\right)_{4}\right]$ and $\mathrm{Na}_{2}\left[\mathrm{Mn}\left(\mathrm{NH}_{2}\right)_{4}\right]$, the $-\mathrm{NH}_{2}$ moiety is coordinated with both alkalis and manganese cations, ${ }^{[3 a, 4 a, 7]}$ which is resemble to the micro environment of $\mathrm{NH}_{\mathrm{x}}$ adsorbed on transition metal surfaces. Meanwhile, structures of transition metal amides can also be stabilized by the addition of alkali metals. Having TM, A, $\mathrm{N}$ and $\mathrm{H}$, ternary amides genetically have linkage to the catalysis of ammonia decomposition and synthesis. However, to the best of our knowledge, such application has not yet to be explored. Therefore, it would be interesting to investigate the role of the ternary transition metal amides in catalyzing ammonia decomposition as well as the more important ammonia synthesis process.

In this work, a new ternary manganese amide, i.e., $\mathrm{Rb}_{2}\left[\mathrm{Mn}\left(\mathrm{NH}_{2}\right)_{4}\right]$, was successfully synthesized for the first time by ball milling rubidium and manganese in the molar ratio of 2:1. $\mathrm{Rb}_{2}\left[\mathrm{Mn}\left(\mathrm{NH}_{2}\right)_{4}\right]$ exhibits two different crystalline structures depending on the application temperatures. The possibility of 
using $\mathrm{Rb}_{2}\left[\mathrm{Mn}\left(\mathrm{NH}_{2}\right)_{4}\right]$ and $\mathrm{K}_{2}\left[\mathrm{Mn}\left(\mathrm{NH}_{2}\right)_{4}\right]$ for catalytic ammonia decomposition and synthesis was investigated.

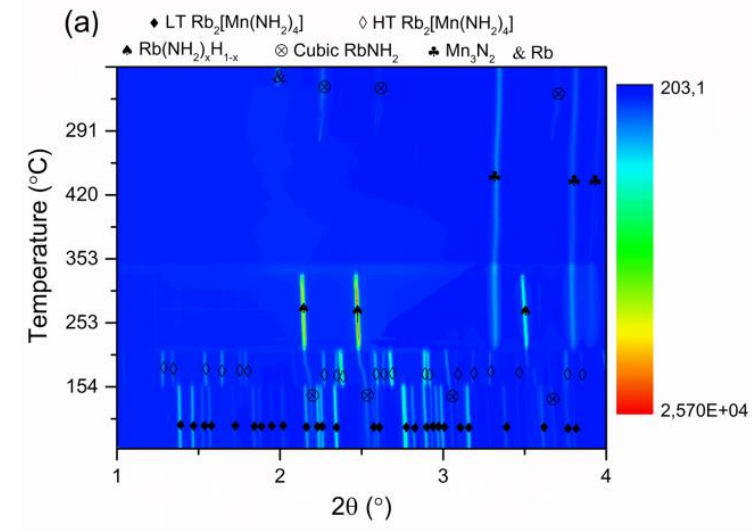

(b)

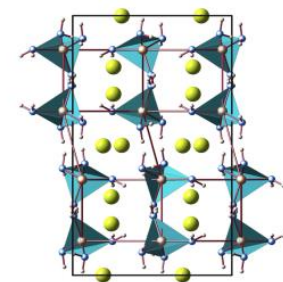

(c)

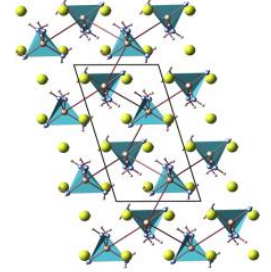

DTA(mW/mg)
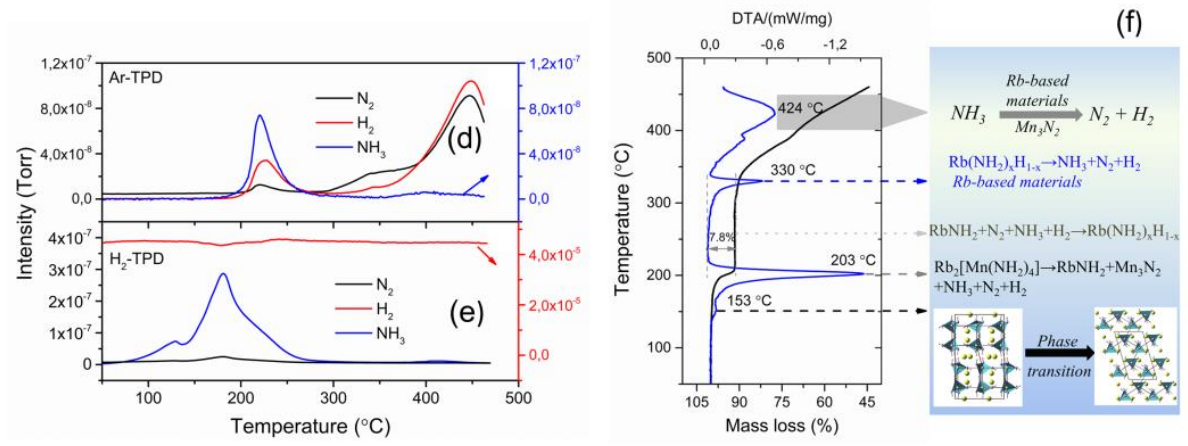

Figure 1. (a) In situ SR-PXD measurement of $\mathrm{Rb}_{2}\left[\mathrm{Mn}\left(\mathrm{NH}_{2}\right)_{4}\right]$ under static vacuum. The sample was heated from $\mathrm{RT}^{\mathrm{T}}$ to $420{ }^{\circ} \mathrm{C}$ with a heating rate of $10{ }^{\circ} \mathrm{C}$ min ${ }^{-1}$ and then it was kept at $420^{\circ} \mathrm{C}$ for 10 min before cooling down to $\mathrm{RT}$ (room temperature). (b) Low-temperature crystal structure $(100)$ view of $\mathrm{Rb}_{2}\left[\mathrm{Mn}\left(\mathrm{NH}_{2}\right)_{4}\right]\left(56{ }^{\circ} \mathrm{C}\right)$ and (c) High-temperature crystal structure (010) view of $\mathrm{Rb}_{2}\left[\mathrm{Mn}\left(\mathrm{NH}_{2}\right)_{4}\right]\left(156{ }^{\circ} \mathrm{C}\right)$. The $\left[\mathrm{Mn}\left(\mathrm{NH}_{2}\right)_{4}\right]^{2-}$ tetrahedra are highlighted in blue. The solid red lines connecting the centers of $\left[\mathrm{Mn}\left(\mathrm{NH}_{2}\right)_{4}\right]^{2-}$ tetrahedra (i.e. Mn atoms) are visual aids and have no other significance. (d) Ar-TPR and (e) $\mathrm{H}_{2}-\mathrm{TPR}$ curves of Rb $2\left[\mathrm{Mn}\left(\mathrm{NH}_{2}\right)_{4}\right]$, heated from 30 to $470{ }^{\circ} \mathrm{C}$ with a heating rate of $5^{\circ} \mathrm{C} \mathrm{min}{ }^{-1}$, under $50 \mathrm{ml} \mathrm{min}^{-1}$ argon and hydrogen flows, respectively. (f) TG-DTA curves of Rb2[Mn(NH T $_{4} 4$, heated from 30 to $470{ }^{\circ} \mathrm{C}$ with a heating rate of $5^{\circ} \mathrm{C} \mathrm{min}-1$, under $50 \mathrm{ml} \mathrm{min}^{-1}$ argon flow.

$\mathrm{Rb}_{2}\left[\mathrm{Mn}\left(\mathrm{NH}_{2}\right)_{4}\right]$ and $\mathrm{K}_{2}\left[\mathrm{Mn}\left(\mathrm{NH}_{2}\right)_{4}\right]$ were prepared by ball milling $\mathrm{Mn}$ and $\mathrm{Rb} / \mathrm{K}$ metals in a molar ratio of $1: 2$ at $\mathrm{RT}$ under 0.7 $\mathrm{MPa}$ of $\mathrm{NH}_{3}$ for $12 \mathrm{~h}$. The crystal structure as well as the thermal decomposition reaction path of the as-synthesized $\mathrm{Rb}_{2}\left[\mathrm{Mn}\left(\mathrm{NH}_{2}\right)_{4}\right]$ were investigated via in situ SR-PXD under static vacuum (Figure 1(a)). From the diffraction patterns the crystal structure of the starting material can be solved using an orthorhombic cell (space group Pbca, No.61) with lattice parameters of $a=7.2183(4) \AA$, $b=10.7474(6) \AA, c=18.3155(10) \AA$, and $V=1420.88(19) \AA^{3}$ (low temperature phase: LT phase (Figure 1(b)). After heating to ca. $156{ }^{\circ} \mathrm{C} \mathrm{LT} \mathrm{Rb} b_{2}\left[\mathrm{Mn}\left(\mathrm{NH}_{2}\right)_{4}\right]$ converts to a high temperature phase (HT phase), which is assigned to a monoclinic structure $\left(P 2_{1} / C\right.$, No.14) with lattice parameters of: $a=7.8536(5) \AA, b=6.9449(5) \AA$, $c=13.8411$ (11) $\AA, \beta=106.389(7)$, and $V=724.24(12) \AA^{3}$ (Figure 1(c)). In both crystal structures $\mathrm{Mn}^{2+}$ are tetrahedrally coordinated by four $\mathrm{NH}_{2}^{-}$, forming $\left[\mathrm{Mn}\left(\mathrm{NH}_{2}\right)_{4}\right]^{2-}$ complex anions. These complex anions then arrange in different anion arrays in LT and $\mathrm{HT}$ phases and $\mathrm{Rb}^{+}$cations are located in the cavities between these complex anions. Corresponding Rietveld fits are shown in Figure S1 and S2. About 4.57 wt \% of cubic $\mathrm{RbNH}_{2}$ is also detected along with $\mathrm{Rb}_{2}\left[\mathrm{Mn}\left(\mathrm{NH}_{2}\right)_{4}\right]$ at temperatures below $210{ }^{\circ} \mathrm{C}$ (Figure S2). The detected phases are $\mathrm{Mn}_{3} \mathrm{~N}_{2}$ and a Rb-based solid solution $\left(\mathrm{Rb}\left(\mathrm{NH}_{2}\right)_{x} \mathrm{H}_{1-x}\right)$ in the temperature range from 210 to $330{ }^{\circ} \mathrm{C}$ (Figure $1(\mathrm{a})$ ). The $\mathrm{Rb}\left(\mathrm{NH}_{2}\right)_{\mathrm{x}} \mathrm{H}_{1-\mathrm{x}}$ is most likely formed
(Figure S3) similar to the reaction of $\mathrm{xKNH}_{2}-(1-\mathrm{x}) \mathrm{KH}^{\left[{ }^{[11]}\right.}$ the detailed results will be given in a separate paper. The formation of amide-hydride solid solution may play a role in catalyzing ammonia synthesis, which will be discussed later. After cooling down to $45^{\circ} \mathrm{C}$, the final products are cubic $\mathrm{RbNH}_{2}$, metallic $\mathrm{Rb}$ and $\mathrm{Mn}_{3} \mathrm{~N}_{2}$.

Temperature-programmed-reaction (TPR) for the assynthesized $\mathrm{Rb}_{2}\left[\mathrm{Mn}\left(\mathrm{NH}_{2}\right)_{4}\right]$ was carried out under $\mathrm{Ar}$ and $\mathrm{H}_{2}$ flows, the released gaseous products were recorded by a mass spectrometry (MS) (Figure $\mathbf{1}$ (d) and (e)). Three MS events are observed at around 210,330 and $440^{\circ} \mathrm{C}$ in Ar-TPR (Figure 1(d)). $\mathrm{NH}_{3}, \mathrm{~N}_{2}$ and $\mathrm{H}_{2}$ co-exist in the first MS peak, however, only a slight trace of $\mathrm{NH}_{3}$ can be detected in the second and the third MS signals, whilst the evolution of huge amounts of $\mathrm{N}_{2}$ and $\mathrm{H}_{2}$ are detected above $300^{\circ} \mathrm{C}$. In contrast to the Ar-TRR, $\mathrm{H}_{2}$-TPR (Figure 1(e)) shows $\mathrm{NH}_{3}$ starts to form at ca. $80^{\circ} \mathrm{C}$ and reaches its peak temperature at around $180^{\circ} \mathrm{C}$. Such a low onset temperature for $\mathrm{NH}_{3}$ formation indicates the dissociation of $\mathrm{H}_{2}$ as well as the hydrogenation of $\mathrm{NH}_{x}$ moiety to form $\mathrm{NH}_{3}$ is an energy-favorable pathway. Since both reactions are involved in the transition metalcatalyzed ammonia synthesis process, $\mathrm{H}_{2}$-TPR result show a potential similar application of $\mathrm{Rb}_{2}\left[\mathrm{Mn}\left(\mathrm{NH}_{2}\right)_{4}\right]$ in catalysis. These unique distinct TPR properties under different gaseous 
atmospheres suggest $\mathrm{Rb}_{2}\left[\mathrm{Mn}\left(\mathrm{NH}_{2}\right)_{4}\right]$ cold be a novel material for ammonia decomposition and synthesis.

Thermal decomposition events of the as-synthesized $\mathrm{Rb}_{2}\left[\mathrm{Mn}\left(\mathrm{NH}_{2}\right)_{4}\right]$ was also investigated by TG-DTA measurement under argon flow (Figure 1(f)). The first endothermic peak at $153^{\circ} \mathrm{C}$ in TG-DTA correlates well with the LT-HT phase transition temperature $\left(156{ }^{\circ} \mathrm{C}\right)$ shown in Figure $1(\mathrm{a})$. The second endothermic signal occurs at $203^{\circ} \mathrm{C}$, at the same time, a mass loss of about $7.8 \%$ is detected from the TG curve; no further mass losses are detected until the temperature reaches the third endothermic event at $330{ }^{\circ} \mathrm{C}$. The fourth endothermic event happens around $440{ }^{\circ} \mathrm{C}$ with a stupendous mass loss. The second, third and fourth endothermic signals in the DTA measurement correspond to those Ar-TPR events at around 210, 330 and $440{ }^{\circ} \mathrm{C}$ in Figure $1(\mathrm{~d})$ ). Combination of the in situ SRPXD (Figure 1(a)), the Ar-TPR (Figure 1(d)), and the weight loss (Figure $1(f)$ ), the process at $210{ }^{\circ} \mathrm{C}$ can be represented by reaction (2). It can also be seen that the theoretical weight loss of the reaction 2 is $7.8 \%$, which well matches the observed value well in Figure 1(f).

$6 \mathrm{Rb}_{2}\left[\mathrm{Mn}\left(\mathrm{NH}_{2}\right)_{4}\right] \rightarrow 12 \mathrm{RbNH}_{2}+2 \mathrm{Mn}_{3} \mathrm{~N}_{2}+6 \mathrm{NH}_{3}+\mathrm{N}_{2}+3 \mathrm{H}_{2}$ (2) After the occurrence of reaction 2, $\mathrm{RbNH}_{2}$ is likely to change to $\mathrm{Rb}\left(\mathrm{NH}_{2}\right)_{x} \mathrm{H}_{1-x}$ as observed in Figure 1(a). Increasing the reaction temperatures, at ca. $330{ }^{\circ} \mathrm{C} \mathrm{Rb}\left(\mathrm{NH}_{2}\right)_{x} \mathrm{H}_{1-x}$ may decompose to some $\mathrm{Rb}$-based species (Rb-N-H species) and release $\mathrm{N}_{2}, \mathrm{H}_{2}$ and $\mathrm{NH}_{3}$. Following that, $\mathrm{NH}_{3}$ is decomposed by the synergetic effect of Rb-based materials and $\mathrm{Mn}_{3} \mathrm{~N}_{2}$, which may be similar to the case of $\mathrm{MnN}-\mathrm{NaNH}_{2}$ and $\mathrm{MnN}-\mathrm{KNH}_{2}$ reported by Chang et al. ${ }^{[12]}$ It is possible that $\mathrm{Mn}_{3} \mathrm{~N}_{2}$ may facilitate the $\mathrm{NH}_{\mathrm{x}}$ coupling on $\mathrm{Rb}$ based species to form $\mathrm{N}_{2}, \mathrm{H}_{2}$, Rb metal, $\mathrm{Rb}\left(\mathrm{NH}_{2}\right)_{x} \mathrm{H}_{1-x}$ or $\mathrm{RbH}$ intermediates. The subsequently formed $\mathrm{Rb}$ metal or $\mathrm{RbH}$ can react with the rest $\mathrm{NH}_{3}$ to form $\mathrm{RbNH}_{2}$, which would then initiate another cycle of ammonia decomposition. In the following, the possible catalytic role of $\mathrm{Rb}_{2}\left[\mathrm{Mn}\left(\mathrm{NH}_{2}\right)_{4}\right]$ amide in $\mathrm{NH}_{3}$ decomposition was tested.

Under the reaction conditions of $\mathrm{NH}_{3}$ decomposition, the $\mathrm{Rb}$ metal or $\mathrm{RbH}$ intermediate species can further react with $\mathrm{NH}_{3}$ to regenerate $\mathrm{RbNH}_{2} / \mathrm{Rb}\left(\mathrm{NH}_{2}\right)_{\times} \mathrm{H}_{1-\mathrm{x}}$. In order to investigate this phenomenon further, the $\mathrm{NH}_{3}$ decomposition properties of $\mathrm{Rb}_{2}\left[\mathrm{Mn}\left(\mathrm{NH}_{2}\right)_{4}\right], \mathrm{K}_{2}\left[\mathrm{Mn}\left(\mathrm{NH}_{2}\right)_{4}\right]$ as well as the reference $\mathrm{MnN}$ were studied (Figure 2(a)). $\mathrm{K}_{2}\left[\mathrm{Mn}\left(\mathrm{NH}_{2}\right)_{4}\right]$ was chosen based on its similarities with $\mathrm{Rb}_{2}\left[\mathrm{Mn}\left(\mathrm{NH}_{2}\right)_{4}\right]$ (Figures $\mathrm{S} 4$ and $\mathrm{S} 5$ ). $\mathrm{MnN}$ is selected as a reference catalyst because it is stable under a certain concentration of ammonia which is the precursor for $\mathrm{NH}_{3}$ decomposition and the product of $\mathrm{NH}_{3}$ synthesis. ${ }^{[13]}$ The decomposition of $\mathrm{NH}_{3}$ over $\mathrm{Rb}_{2}\left[\mathrm{Mn}\left(\mathrm{NH}_{2}\right)_{4}\right]$ and $\mathrm{K}_{2}\left[\mathrm{Mn}\left(\mathrm{NH}_{2}\right)_{4}\right]$ starts at around $350{ }^{\circ} \mathrm{C}$, which is close to the main appearance temperature of $\mathrm{N}_{2}$ and $\mathrm{H}_{2}$ in the Ar-TPR spectra (Figure 1(d)). This ammonia decomposition temperature is similar to those of the noble metal catalysts for ammonia decomposition. ${ }^{[13]}$ At $500{ }^{\circ} \mathrm{C}$, both amide systems show good $\mathrm{NH}_{3}$ decomposition properties. At this temperature, the $\mathrm{NH}_{3}$ decomposition conversions of $\mathrm{Rb}_{2}\left[\mathrm{Mn}\left(\mathrm{NH}_{2}\right)_{4}\right]$ and $\mathrm{K}_{2}\left[\mathrm{Mn}\left(\mathrm{NH}_{2}\right)_{4}\right]$ reach $68 \%$ and $48 \%$, respectively. These $\mathrm{NH}_{3}$ decomposition conversions are much higher than that of $\mathrm{MnN}(15 \%)$ and similar to that of $\mathrm{Ru} / \mathrm{MgO}$ catalyst ${ }^{[13]}$ under the same reaction conditions. Similar phenomena were found in the previous results using composites catalysts composed of $\mathrm{MnN}$ and $\mathrm{NaNH}_{2} / \mathrm{KNH}_{2}{ }^{\left[{ }^{12]}\right.}$ Both composites show much better catalytic performances than the neat $\mathrm{MnN}$ and $\mathrm{NaNH}_{2} / \mathrm{KNH}_{2}$. The $\mathrm{Na}(\mathrm{K})$-Mn-amide/imide species have been proposed as intermediates during $\mathrm{NH}_{3}$ decomposition reaction of $\mathrm{MnN}-\mathrm{NaNH}_{2} / \mathrm{MnN}-\mathrm{KNH}_{2}{ }^{\left[{ }^{12]}\right.}$
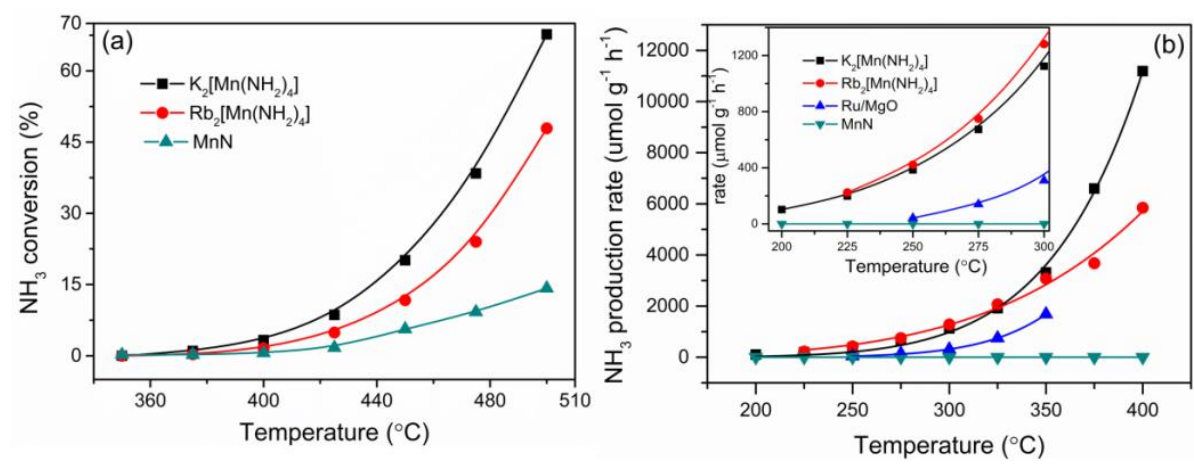

Figure 2. (a) $\mathrm{NH}_{3}$ conversion of $\mathrm{Rb}_{2}\left[\mathrm{Mn}\left(\mathrm{NH}_{2}\right)_{4}\right], \mathrm{K}_{2}\left[\mathrm{Mn}\left(\mathrm{NH}_{2}\right)_{4}\right]$ and $\mathrm{MnN}$ as a function of reaction temperature between 350 and $500{ }^{\circ} \mathrm{C}$. Around $30 \mathrm{mg}$ of each sample is measured at $5 \% \mathrm{NH}_{3}-\mathrm{Ar}$ mixture gas with a flow rate of $30 \mathrm{ml} \mathrm{min}{ }^{-1}$. (b) $\mathrm{NH}_{3}$-synthesis rate of $\mathrm{Rb}_{2}\left[\mathrm{Mn}\left(\mathrm{NH}_{2}\right)_{4}\right], \mathrm{K}_{2}\left[\mathrm{Mn}\left(\mathrm{NH}_{2}\right)_{4}\right], \mathrm{MnN}$ and Ru/MgO as a function of temperature from 200 to $400^{\circ} \mathrm{C}$; Inset is their $\mathrm{NH}_{3}$ synthesis rate in the temperature range of 200 and $300{ }^{\circ} \mathrm{C}$. Around 30 mg of each sample is measured under 10 bar of syngas $\left(\mathrm{N}_{2}: \mathrm{H}_{2}=1: 3\right)$ with a flow rate of $30 \mathrm{ml} \mathrm{min}^{-1}$

According to the microscopic reversibility, a good ammonia decomposition catalyst is also possible good at its reverse reaction, i.e., ammonia synthesis. Considering the good performance of $\mathrm{Rb}_{2}\left[\mathrm{Mn}\left(\mathrm{NH}_{2}\right)_{4}\right]$ in ammonia decomposition as well as the facile hydrogenation property (Figure $1(\mathrm{e})$ ), it is interesting to study its function in ammonia synthesis. In the following, the synthesis of $\mathrm{NH}_{3}$ from syngas using $\mathrm{Rb}_{2}\left[\mathrm{Mn}\left(\mathrm{NH}_{2}\right)_{4}\right]$ and $\mathrm{K}_{2}\left[\mathrm{Mn}\left(\mathrm{NH}_{2}\right)_{4}\right.$ was investigated. During the heating process under a flow of syngas, large amount of ammonia was formed from the reaction of amides and $\mathrm{H}_{2}$ (Figure $1(\mathrm{e})$ and Figure S4). To avoid such artifacts, $\mathrm{Rb}_{2}\left[\mathrm{Mn}\left(\mathrm{NH}_{2}\right)_{4}\right]$ and $\mathrm{K}_{2}\left[\mathrm{Mn}\left(\mathrm{NH}_{2}\right)_{4}\right]$ were heated under the syngas flow from $\mathrm{RT}$ to $250^{\circ} \mathrm{C}$ for a certain time, until the ammonia synthesis rate levels off (Figure S6). The temperature dependence of the $\mathrm{NH}_{3}$ synthesis rate of $\mathrm{Rb}_{2}\left[\mathrm{Mn}\left(\mathrm{NH}_{2}\right)_{4}\right]$ and $\mathrm{K}_{2}\left[\mathrm{Mn}\left(\mathrm{NH}_{2}\right)_{4}\right]$ are displayed in Figure 2(b). The temperature dependence of the $\mathrm{NH}_{3}$ synthesis rate using the catalysts $\mathrm{MnN}$ and $\mathrm{Ru} / \mathrm{MgO}$ are also reported in Figure 2(b) for comparison. In the temperature range between 200 and $350{ }^{\circ} \mathrm{C}$, the neat $\mathrm{MnN}$ does not show any $\mathrm{NH}_{3}$ synthesis activity. However, under the same applied conditions both $\mathrm{Rb}_{2}\left[\mathrm{Mn}\left(\mathrm{NH}_{2}\right)_{4}\right]$ and $\mathrm{K}_{2}\left[\mathrm{Mn}\left(\mathrm{NH}_{2}\right)_{4}\right]$ show excellent catalytic activities on $\mathrm{NH}_{3}$ synthesis rate, which are much better than that of the $\mathrm{Ru} / \mathrm{MgO}$ catalyst. As shown in the inset of Figure 2(b), the synthesis of $\mathrm{NH}_{3}$ with the use of $\mathrm{Rb}_{2}\left[\mathrm{Mn}\left(\mathrm{NH}_{2}\right)_{4}\right]$ and $\mathrm{K}_{2}\left[\mathrm{Mn}\left(\mathrm{NH}_{2}\right)_{4}\right]$ as catalysts precursors is 
observed even at temperatures well below $200^{\circ} \mathrm{C}$, which is $50^{\circ} \mathrm{C}$ lower than that of $\mathrm{Ru} / \mathrm{MgO}$ catalyst. At $225^{\circ} \mathrm{C}$, the $\mathrm{NH}_{3}$ synthesis rates of $\mathrm{Rb}_{2}\left[\mathrm{Mn}\left(\mathrm{NH}_{2}\right)_{4}\right]$ and $\mathrm{K}_{2}\left[\mathrm{Mn}\left(\mathrm{NH}_{2}\right)_{4}\right]$ are 223 and $198 \mu \mathrm{mol}$ $\mathrm{g}^{-1} \mathrm{~h}^{-1}$, respectively. Ammonia synthesis activity increases with increasing temperature. At $350{ }^{\circ} \mathrm{C}$ (Table 1), the activities of $\mathrm{Rb}_{2}\left[\mathrm{Mn}\left(\mathrm{NH}_{2}\right)_{4}\right]$ and $\mathrm{K}_{2}\left[\mathrm{Mn}\left(\mathrm{NH}_{2}\right)_{4}\right]$ reached 3076 and $3313 \mu \mathrm{mol} g$ ${ }^{1} \mathrm{~h}^{-1}$, respectively. These values are more than 3 orders of magnitude higher than that of $\mathrm{MnN}$ and even twice higher than that of $\mathrm{Ru} / \mathrm{MgO}$.

Furthermore, after $15 \mathrm{~h}$ under 10 bar of syngas at $300{ }^{\circ} \mathrm{C}$, the $\mathrm{NH}_{3}$ synthesis rates are still about 1400 and $800 \mu \mathrm{mol}$ $\mathrm{g}^{-1} \mathrm{~h}^{-1}$ for $\mathrm{Rb}_{2}\left[\mathrm{Mn}\left(\mathrm{NH}_{2}\right)_{4}\right]$ and $\mathrm{K}_{2}\left[\mathrm{Mn}\left(\mathrm{NH}_{2}\right)_{4}\right]$, respectively. Therefore, $\mathrm{Rb}_{2}\left[\mathrm{Mn}\left(\mathrm{NH}_{2}\right)_{4}\right]$ and $\mathrm{K}_{2}\left[\mathrm{Mn}\left(\mathrm{NH}_{2}\right)_{4}\right]$ appear to preserve their catalytic activities (Figure S7). Figure $\mathbf{S 8}$ shows that the apparent activation energies $\left(E_{a}\right)$ of $\mathrm{NH}_{3}$ synthesis for

$\mathrm{Rb}_{2}\left[\mathrm{Mn}\left(\mathrm{NH}_{2}\right)_{4}\right]$ and $\mathrm{K}_{2}\left[\mathrm{Mn}\left(\mathrm{NH}_{2}\right)_{4}\right]$ are 54 and $57 \mathrm{~kJ} \mathrm{~mol}^{-1}$ respectively. The much higher $\mathrm{Ea}$ of $\mathrm{Ru} / \mathrm{MgO}$, i.e., $98 \mathrm{~kJ} \mathrm{~mol}^{-1}$ (Table 1), than that of $\mathrm{Rb}_{2}\left[\mathrm{Mn}\left(\mathrm{NH}_{2}\right)_{4}\right]$ and $\mathrm{K}_{2}\left[\mathrm{Mn}\left(\mathrm{NH}_{2}\right)_{4}\right.$ could be due to their different reaction mechanisms compared to these ternary manganese systems.

Table 1. Ammonia synthesis activities of $\mathrm{Rb}_{2}\left[\mathrm{Mn}\left(\mathrm{NH}_{2}\right)_{4}\right], \mathrm{K}_{2}\left[\mathrm{Mn}\left(\mathrm{NH}_{2}\right)_{4}\right]$, $\mathrm{Ru} / \mathrm{MgO}$, and $\mathrm{MnN}$ at $350^{\circ} \mathrm{C}$, And their Ea in the temperature range of $200-350^{\circ} \mathrm{C}$.

\begin{tabular}{lllll}
\hline Name & $\mathrm{Rb}_{2}\left[\mathrm{Mn}\left(\mathrm{NH}_{2}\right)_{4}\right]$ & $\mathrm{K}_{2}\left[\mathrm{Mn}\left(\mathrm{NH}_{2}\right)_{4}\right]$ & $\mathrm{Ru} / \mathrm{MgO}$ & $\mathrm{MnN}$ \\
\hline $\begin{array}{l}\text { Activities } \\
\left(\mu \mathrm{mol} \mathrm{g}^{-1} \mathrm{~h}^{-1}\right)\end{array}$ & 3076 & 3313 & 1685 & 0 \\
$\mathrm{Ea}\left(\mathrm{kJ} \mathrm{mol}^{-1}\right)$ & 54.4 & 57.3 & 98.4 & - \\
\hline
\end{tabular}
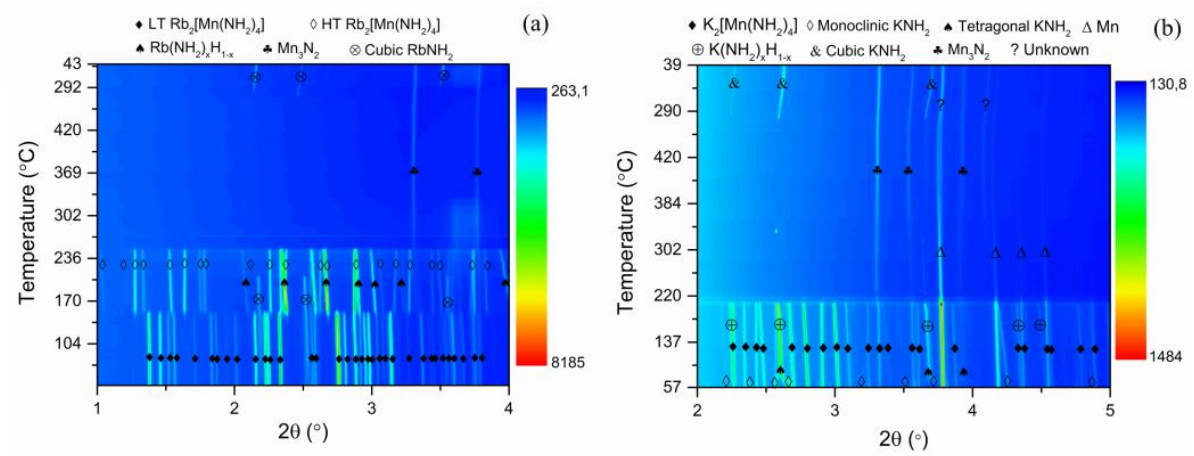

Figure 3. In situ SR-PXD measurements of $(\mathrm{a}) \mathrm{Rb}_{2}\left[\mathrm{Mn}\left(\mathrm{NH}_{2}\right)_{4}\right]$ and $(\mathrm{b}) \mathrm{K}_{2}\left[\mathrm{Mn}\left(\mathrm{NH}_{2}\right)_{4}\right]$ under 10 bar of syngas $\left(\mathrm{N}_{2}-3 \mathrm{H}_{2}\right)$. The samples were heated from $\mathrm{RT}$ to $420{ }^{\circ} \mathrm{C}$ with a heating rate of $10^{\circ} \mathrm{C} \mathrm{min}^{-1}$ and then it was kept at $420{ }^{\circ} \mathrm{C}$ for $10 \mathrm{~min}$ before to be cooled down to RT.

To reveal the interactions of ternary manganese amides and syngas, thermal decompositions of $\mathrm{Rb}_{2}\left[\mathrm{Mn}\left(\mathrm{NH}_{2}\right)_{4}\right]$ and $\mathrm{K}_{2}\left[\mathrm{Mn}\left(\mathrm{NH}_{2}\right)_{4}\right]$ in a closed system under 10 bar of syngas were investigated via in situ SR-PXD (Figure 3). From reaction 2 and Figure $3(\mathrm{a})$, the thermal decomposition of $\mathrm{Rb}_{2}\left[\mathrm{Mn}\left(\mathrm{NH}_{2}\right)_{4}\right]$ could in situ generate $\mathrm{RbNH}_{2}$, which subsequently reacts with $\mathrm{H}_{2}$ to form $\mathrm{RbH}$. The rubidium amide and hydride then react with each other to produce solid solution (reaction 3 ).

$x \mathrm{RbNH}_{2}+(1-\mathrm{x}) \mathrm{RbH} \rightarrow \mathrm{Rb}\left(\mathrm{NH}_{2}\right)_{x} \mathrm{H}_{1-x}$

Different from the reaction under vacuum (Figure 1(a)), $\mathrm{Rb}\left(\mathrm{NH}_{2}\right)_{\times} \mathrm{H}_{1-x}$ co-exists only with $\mathrm{HT} \mathrm{Rb}_{2}\left[\mathrm{Mn}\left(\mathrm{NH}_{2}\right)_{4}\right]$ below $250^{\circ} \mathrm{C}$ under syngas. The decomposition temperature of HT $\mathrm{Rb}_{2}\left[\mathrm{Mn}\left(\mathrm{NH}_{2}\right)_{4}\right]$ is shifted to $250^{\circ} \mathrm{C}$, which is $40^{\circ} \mathrm{C}$ higher than that observed under vacuum atmosphere. The Rietveld refinements of the SR-PXD patterns acquired for $\mathrm{Rb}_{2}\left[\mathrm{Mn}\left(\mathrm{NH}_{2}\right)_{4}\right]$ in syngas under different temperatures are reported in Figures $\mathbf{S 9}$ and $\mathbf{S 1 0}$. Figure $3(\mathrm{~b})$ shows the decomposition process of $\mathrm{K}_{2}\left[\mathrm{Mn}\left(\mathrm{NH}_{2}\right)_{4}\right]$ under 10 bar of syngas. The presence of $\mathrm{K}_{(}\left(\mathrm{NH}_{2}\right)_{\mathrm{x}} \mathrm{H}_{1-\mathrm{x}}$ can be detected below $220{ }^{\circ} \mathrm{C}$, which is different from that performed under vacuum (Figure S11), Under vacuum the $\mathrm{K}\left(\mathrm{NH}_{2}\right)_{\mathrm{x}} \mathrm{H}_{1-\mathrm{x}}$ stabilizes up to around $400{ }^{\circ} \mathrm{C}$. Under syngas atmosphere, at temperatures higher than $250{ }^{\circ} \mathrm{C}$ the in situ SR-PXD results (Figure 3) do not show diffraction peaks of $\mathrm{Rb}\left(\mathrm{NH}_{2}\right)_{x} \mathrm{H}_{1}$. $\left.{ }_{x} / \mathrm{K}_{(} \mathrm{NH}_{2}\right)_{x} \mathrm{H}_{1-x}$ probably because these phases are in a molten state.

Under the flow of 10 bar syngas, the reaction intermediates could be different from what are observed in the closed system, because of the different gas phase chemical potential. The PXD of the products obtained after the $\mathrm{NH}_{3}$ synthesis experiment using $\mathrm{Rb}_{2}\left[\mathrm{Mn}\left(\mathrm{NH}_{2}\right)_{4}\right]$ and $\mathrm{K}_{2}\left[\mathrm{Mn}\left(\mathrm{NH}_{2}\right)_{4}\right]$ in the flow system was plotted in Figure S12, where $\mathrm{Mn}_{2} \mathrm{~N}$ and $\mathrm{Mn}_{4} \mathrm{~N}$ are observed. Differently from the flow system, the only detected Mn-based phase is $\mathrm{Mn}_{3} \mathrm{~N}_{2}$ in the in situ SR-PXD (Figures 1(a) and 3 ), which could be due to the relatively higher partial pressure of ammonia in the closed system coming from the decomposition of $\mathrm{Rb}_{2}\left[\mathrm{Mn}\left(\mathrm{NH}_{2}\right)_{4}\right] / \mathrm{K}_{2}\left[\mathrm{Mn}\left(\mathrm{NH}_{2}\right)_{4}\right]$, which hinders the formation of the $\mathrm{N}$-deficient nitride phases such as $\mathrm{Mn}_{2} \mathrm{~N}$ and $\mathrm{Mn}_{4} \mathrm{~N} \cdot{ }^{[14]}$

It should be highlighted that $\mathrm{TM}(\mathrm{N}) \mathrm{s}-\mathrm{LiH}$ composites has recently been reported for ammonia synthesis by our coauthors Chen et al. ${ }^{[15]}$. TM(N)s-LiH composites show high catalytic activities in the temperature range of $150-327^{\circ} \mathrm{C}$. The improved catalytic properties of the TM(N)s-LiH composites has been proposed to be related to the introduction of a second active center (i.e. $\mathrm{LiH}$ ) beside that of $\mathrm{TM}(\mathrm{N})$ s surfaces, which breaks the intrinsic scaling relations on transition metal surfaces. The second active center $\mathrm{LiH}$ can effectively pull $\mathrm{N}_{\mathrm{ad}}$ away from the $\mathrm{TM}(\mathrm{N})$ surface, and perform the hydrogenation of $\mathrm{N}_{\mathrm{ad}}$ Outside of transition metal surface. The production of $\mathrm{NH}_{3}$ in the TM(N)s-LiH composites can be divided into 3 different steps (reaction 4-7). [15]

$$
\begin{aligned}
& \mathrm{N}_{2} \rightarrow \mathrm{N}_{\mathrm{ad}} \\
& \mathrm{LiH}+\mathrm{N}_{\mathrm{ad}} \rightarrow[\mathrm{LiNH}] \\
& {[\mathrm{LiNH}]+\mathrm{H}_{2} \rightarrow \mathrm{NH}_{3}+\mathrm{LiH}}
\end{aligned}
$$

Overall reaction: $\mathrm{N}_{2}+3 \mathrm{H}_{2} \rightarrow 2 \mathrm{NH}_{3}$

Based on the results obtained via TPR reactions (Figures 1(d) and (e)), in situ SR-PXD (Figures 1(a) and 3) and 
$\mathrm{NH}_{3}$ synthesis activity (Figure 2(b)), it is reasonable to deduce that $\mathrm{Rb}_{2}\left[\mathrm{Mn}\left(\mathrm{NH}_{2}\right)_{4}\right]$ and $\mathrm{K}_{2}\left[\mathrm{Mn}\left(\mathrm{NH}_{2}\right)_{4}\right]$ may follow a similar reaction mechanism as the LiH-Mn composite. That is, $\mathrm{Mn}$ nitride is responsible for $\mathrm{N}_{2}$ dissociation to generate the adsorbed $\mathrm{N}$ atoms,

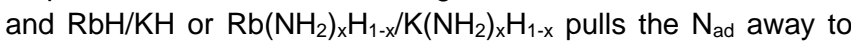
form $\mathrm{NH}_{\mathrm{x}}$ species, which is then followed by hydrogenation to release $\mathrm{NH}_{3}$.

The observed amide-hydride solid solutions in the in situ SR-PXD measurements indicate they may be thermodynamically stable under a certain condition. Under this reaction condition of ammonia synthesis, although the amide-hydride crystalline phase was not observed, it is still possible that an amorphous layer of solid solutions exists on the interface of $\mathrm{Mn}$ nitride and hydride. The $\mathrm{RbNH}_{2}$ or $\mathrm{KNH}_{2}$ formed after $\mathrm{N}$ transfer may migrate away to form relatively more stable amide-hydride species, or it could also be reacted with manganese nitride to product amorphous $\mathrm{Rb}_{2} / \mathrm{K}_{2}\left[\mathrm{Mn}\left(\mathrm{NH}_{2}\right)_{\mathrm{x}}\right]$ under the ammonia atmosphere. This process may be important for catalytic ammonia synthesis; because the migration of $\mathrm{RbNH}_{2}$ or $\mathrm{KNH}_{2}$ may lead to clean hydride sites on the interface for further $\mathrm{N}$ transfer reactions. To verify this, a detailed characterization using in situ FTIR or Raman as well as theoretical calculations may be beneficial, which would be our following works.

\section{Acknowledgements}

This work was supported by the project of Chinese Academy of Science - Helmholtz collaborative project "RevHy" - "Study on the synthesis, structures and performances of complex hydrides systems for Reversible high capacity Hydrogen storage at low temperatures" and project of National Natural Science Foundation of China (21603220). We also thank the access to using equipment from the Helmholtz Energy Materials Characterization platform which is financially supported by The Helmholtz Foundation. Author 1 and Author 2 contributed equally to this work.

Keywords: Ternary transition metal amide - Transition metal nitride $\cdot$ Ammonia synthesis $•$ Ammonia decomposition

\section{References}

[1] aP. Chen, Z. Xiong, J. Luo, J. Lin, K. L. Tan, Nature 2002, 420, 302 304; bZ. Xiong, G. Wu, J. Hu, P. Chen, Advanced Materials 2004 16, 1522-1525; cS.-i. Orimo, Y. Nakamori, J. R. Eliseo, A. Züttel, C M. Jensen, Chemical Reviews 2007, 107, 4111-4132; dJ. Yang, A. Sudik, C. Wolverton, D. J. Siegel, Chemical Society Reviews 2010 39, 656-675; eG. Xia, D. Li, X. Chen, Y. Tan, Z. Tang, Z. Guo, H Liu, Z. Liu, X. Yu, Advanced Materials 2013, 25, 6238-6244; fP Chen, E. Akiba, S.-i. Orimo, A. Zuettel, L. Schlapbach, in Hydrogen Science and Engineering: Materials, Processes, Systems and Technology, Wiley-VCH Verlag GmbH \& Co. KGaA, 2016, pp. 763790.

[2] aW. I. F. David, J. W. Makepeace, S. K. Callear, H. M. A. Hunter, J. D. Taylor, T. J. Wood, M. O. Jones, Journal of the American Chemical Society 2014, 136, 13082-13085; bJ. Guo, Z. Chen, A Wu, F. Chang, P. Wang, D. Hu, G. Wu, Z. Xiong, P. Yu, P. Chen, Chemical Communications 2015, 51, 15161-15164; cP. L. Bramwell, S. Lentink, P. Ngene, P. E. de Jongh, The Journal of Physical Chemistry C 2016, 120, 27212-27220; dJ. W. Makepeace, T. J. Wood, H. M. A. Hunter, M. O. Jones, W. I. F. David, Chemical Science 2015, 6, 3805-3815.
In summary, $\mathrm{Rb}_{2}\left[\mathrm{Mn}\left(\mathrm{NH}_{2}\right)_{4}\right]$ has been successfully synthesized by mechanochemical reaction under mild conditions for the first time. $\mathrm{Rb}_{2}\left[\mathrm{Mn}\left(\mathrm{NH}_{2}\right)_{4}\right]$ possesses two distinct crystalline phases depending on the application temperatures. The crystal structures of both phases were successfully solved using combined SR-PXD and first-principles calculations. The determined crystal structures confirm the coexistence of the TM and the alkali metal active centers, which was previously reported to be critical for ammonia production catalysis. Both $\mathrm{Rb}_{2}\left[\mathrm{Mn}\left(\mathrm{NH}_{2}\right)_{4}\right]$ and $\mathrm{K}_{2}\left[\mathrm{Mn}\left(\mathrm{NH}_{2}\right)_{4}\right]$ show excellent $\mathrm{NH}_{3}$ decomposition and synthesis activities, especially at low temperatures. In the temperature range of 250 to $350{ }^{\circ} \mathrm{C}$, the $\mathrm{NH}_{3}$ synthesis rates of $\mathrm{Rb}_{2}\left[\mathrm{Mn}\left(\mathrm{NH}_{2}\right)_{4}\right]$ and $\mathrm{K}_{2}\left[\mathrm{Mn}\left(\mathrm{NH}_{2}\right)_{4}\right]$ under syngas atmosphere are more than 3 orders of magnitude higher than the reference $\mathrm{MnN}$ catalyst, and are even higher than that reported for the noble metal catalysts. To the best of our knowledge, this is the first reported case of using only amide for ammonia synthesis. The key factor contributed to this unexpected behavior is most likely the continuous variation of hydride-amide on the surface of manganese nitrides under syngas atmosphere, which shed lights on promoting nitrides for heterogeneous catalysis by compositing nitrides and alkali hydrides/amides. In addition, the application of ternary transition amide is extended to heterogeneous catalysis for the first time.
aB. Fröhling, $\mathrm{H}$. Jacobs, Zeitschrift für anorganische und allgemeine Chemie 1997, 623, 1108-1112; bM. Drew, L. Guémas, P. Chevalier, P. Palvadeau, J. Rouxel, Rev. Chim. Min 1975, 12, 419-426. $\mathrm{aB}$. Fröhling, $\mathrm{H}$. Jacobs, Zeitschrift für anorganische und allgemeine Chemie 1997, 623, 1103-1107; bT. M. M. Richter, N. S. A. Alt, E. Schlücker, R. Niewa, Zeitschrift für anorganische und allgemeine Chemie 2016, 642, 1207-1211.

aH. Cao, T. M. M. Richter, C. Pistidda, A.-L. Chaudhary, A. Santoru, G. Gizer, R. Niewa, P. Chen, T. Klassen, M. Dornheim, ChemSusChem 2015, 8, 3777-3782; bH. Cao, A. Santoru, C. Pistidda, T. M. M. Richter, A.-L. Chaudhary, G. Gizer, R. Niewa, P. Chen, T. Klassen, M. Dornheim, Chemical Communications 2016 52, 5100-5103; cH. Cao, C. Pistidda, T. M. M. Richter, A. Santoru, C. Milanese, S. Garroni, J. Bednarcik, A.-L. Chaudhary, G. Gizer, H.-P. Liermann, R. Niewa, C. Ping, T. Klassen, M. Dornheim, The Journal of Physical Chemistry C 2017, 121, 1546-1551.

T. Richter, R. Niewa, Inorganics 2014, 2, 29-78.

T. M. Richter, S. Zhang, R. Niewa, Zeitschrift für KristallographieCrystalline Materials 2013, 228, 351-358.

T. M. M. Richter, N. S. A. Alt, E. Schlücker, R. Niewa, Zeitschrift für anorganische und allgemeine Chemie 2015, 641, 1016-1023. aG. Ertl, M. Huber, Journal of Catalysis 1980, 61, 537-539; bR Schlögl, Angewandte Chemie International Edition 2003, 42, 2004 2008; cG. Ertl, Angewandte Chemie International Edition 2008, 47 3524-3535; dA.-H. Lu, J.-J. Nitz, M. Comotti, C. Weidenthaler, K. Schlichte, C. W. Lehmann, O. Terasaki, F. Schüth, Journal of the American Chemical Society 2010, 132, 14152-14162; eW. Zheng, T. P. Cotter, P. Kaghazchi, T. Jacob, B. Frank, K. Schlichte, W. Zhang, D. S. Su, F. Schüth, R. Schlögl, Journal of the American Chemical Society 2013, 135, 3458-3464.

K.-i. Aika, H. Hori, A. Ozaki, Journal of Catalysis 1972, 27, 424-431. A. Santoru, C. Pistidda, M. H. Sorby, M. R. Chierotti, S. Garroni, E. Pinatel, F. Karimi, H. Cao, N. Bergemann, T. T. Le, J. Puszkiel, R Gobetto, M. Baricco, B. C. Hauback, T. Klassen, M. Dornheim, Chemical Communications 2016, 52, 11760-11763.

F. Chang, J. Guo, G. Wu, P. Wang, P. Yu, P. Chen, Catalysis Today 2017, 286, 141-146.

P. Yu, J. Guo, L. Liu, P. Wang, F. Chang, H. Wang, X. Ju, P. Chen, The Journal of Physical Chemistry C 2016, 120, 2822-2828.

N. A. Gokcen, Bulletin of Alloy Phase Diagrams 1990, 11, 33.

P. Wang, F. Chang, W. Gao, J. Guo, G. Wu, T. He, P. Chen, Nat Chem 2017, 9, 64-70. 


\section{Entry for the Table of Contents}

\section{COMMUNICATION}

The first case of using $\mathrm{A}_{2}\left[\mathrm{Mn}\left(\mathrm{NH}_{2}\right)_{4}\right](\mathrm{A}=\mathrm{Rb}$ and $\mathrm{K})$ for low temperature $\mathrm{NH}_{3}$ synthesis and decomposition.

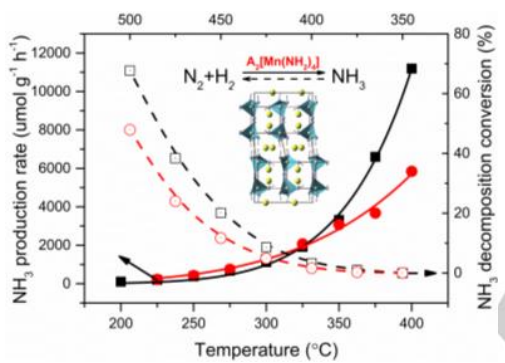

Hujun Cao, ${ }^{\star \neq}$ Jianping Guo ${ }^{\ddagger}, \mathrm{Fei}$ Chang, Claudio Pistidda, Wei Zhou, Xilun Zhang, Hui Wu, Antonio Santoru, Norbert Schell, Rainer Niewa, Ping Chen, Thomas Klassen, and Martin Dornheim

Page No. - Page No.

Transition and Alkali Metal Complex Ternary Amides for Ammonia Synthesis and Decomposition 